\title{
弁ばね用材料の回転曲げ疲労に及ぼす要因*
}

\section{Effect of Processes on Rotating Bending Fatigue Strength of Si-Cr Valve Spring Wire}

小曽根 敏夫**.土方 直樹**

Toshio OZONE $\cdot$ Naoki HIJIKATA

\begin{abstract}
弁ばね用材料の疫れ強さの評価は，一般に素線においては中村式回転曲げ瘦れ試験により評 価する場合が多い.しかし回転曲げ疲れ試験と星型ばね疲れ試験は，折損形態の違いから考之 ると回転曲げで得られた結果をそのまま，ばねの疲れ強さに置き換える訳にはいかないと思わ れる。そこで本報では，中村式回転曲げ疲れ試験機により，SWOSC-V を用い，加熱温度と， ショット投射時間を変えて実験を行なった結果, 回転曲げ疲れ強さは, 引張強さと表面粗さに 大きく支配されることがわかった。
\end{abstract}

Rotating bending fatigue test (of Nakamura type) is usually applied to valve spring wires to estimate the fatigue strength, but it seems difficult to use it for the evaluation of fatigue strength of valve springs, for fatigue characteristics seen in wires and springs are quite different. This paper presents effects of annealing temperatures and shot peening operation on the rotating bending fatigue strength of $\mathrm{Si}-\mathrm{Cr}$ oil tempered wire to conclude that the fatigue strength of the wire is strongly affected with its tensile strength and surface roughness.

\section{1. まえがき}

最近の弁ばねは, 自動車エンジンの小型化・高出力 化に伴い, 高応力下における高い耐久性が求められて きている，その高い耐久性は，各種疲れ試験によって 初めて裏付けられるものである。現在, 疲れ試験は, ばねでは星型ばね疲れ試験, 素線状態では回転曲げ疲 れ試験がその代表として広く用いられている。回転曲 げ疲れ試験は，星型ばね疲れ試験に比べ，試験速度が 速く, 操作も単純なため, 材料評価には欠くことので きない試験法となっている。一般に回転曲げ疲れ試験 用供試材は, 弁ばねに施す処理条件と同じ条件で，処 理する場合が多い。しかし，弁ばねには最適と思われ るこれら処理条件も，回転曲げ疲れ試験では，試験条 件 (回転曲げ疲れ試験は両振り)や折損形態から考える と，必ずしも最適な処理条件とは言い難い.
今回は, 弁ばね用材料の中でも, 耐久性に特にすぐ れている SWOSC-V(弁ばね用シリコンクロム鋼オイル テンパー線)について, 中村式回転曲げ疲れ試験により, 低温焼鈍温度やショットピーニング条件を変えること により，回転曲げ痩れ試験に及ぼす諸条件の影響につ いて調べ，回転曲げ疲れ試験における供試材の最適処 理条件を明らかにすることを目的とする。

\section{2. 供試材及び実験方法}

実験に用いた SWOSC-V は， $\phi 4.0 \mathrm{~mm}$ で化学成分 を表 1 に示す.

図 1 に，今回実験に用いた供試材の組織を示す。組 織は良好なソルバイトを呈し，表面に特に，脱炭など の異常は，認められなかった。

供試材は，それぞれ表 2 に示す工程で作成した。才 イルテンパー線をすべて, $650 \mathrm{~mm}$ に切断した後, 一次

表 1 供試材の化学成分 $(\%)$

\begin{tabular}{|c|c|c|c|c|c|c|c|c|}
\hline SWOSC & $\mathrm{C}$ & $\mathrm{Si}$ & $\mathrm{Mn}$ & $\mathrm{P}$ & $\mathrm{S}$ & $\mathrm{Cu}$ & $\mathrm{Cr}$ & 引張強さ \\
\cline { 2 - 8 }$-\mathrm{V}$ & 0.550 & 1.45 & 0.68 & 0.005 & 0.004 & 0.01 & 0.68 & $198 \mathrm{kgt/mm}$ \\
\hline
\end{tabular}

原稿受付日 绝利 62 年: 12 月 $25 \mathrm{H}$

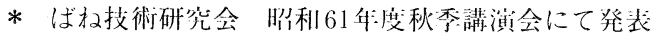

** 中然発條侏) (Chuo Spring Co., Ltd.) 


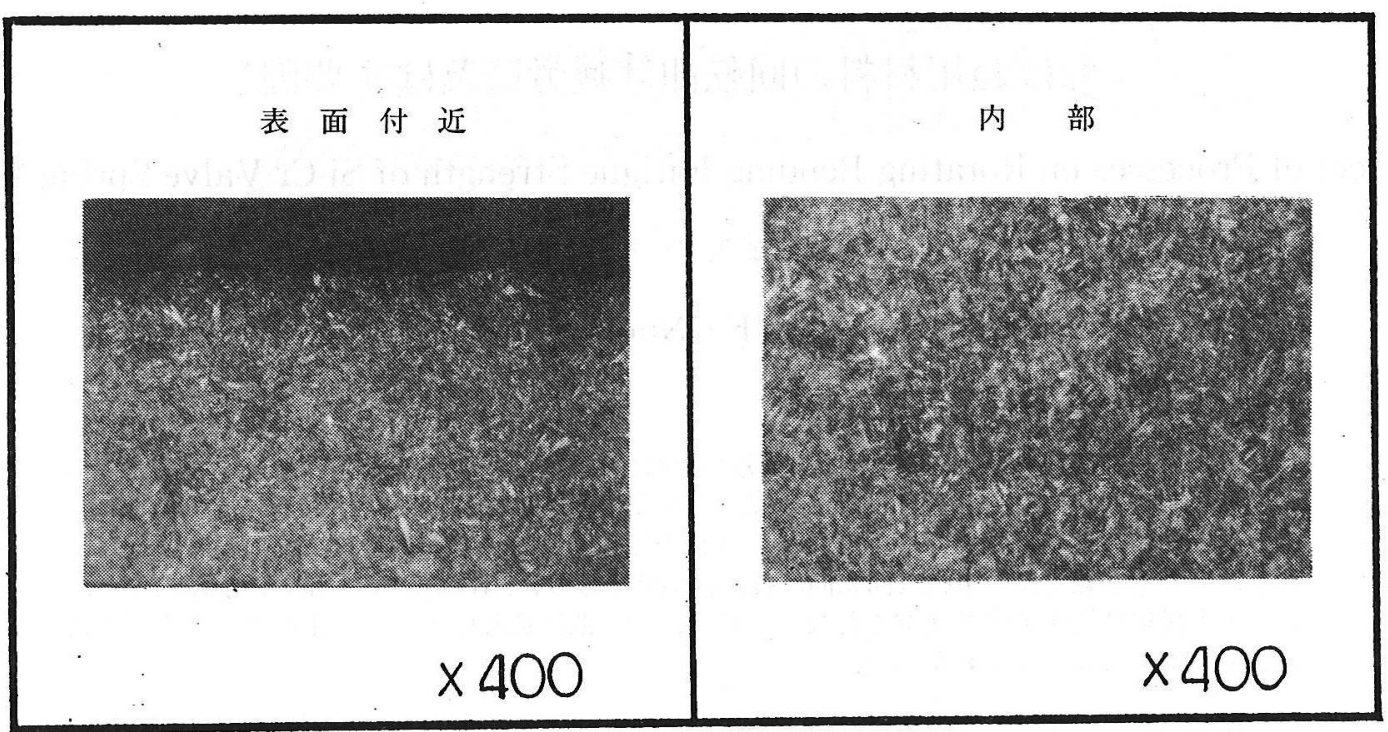

図1，供試材の組織

表 2 供試材処理工程

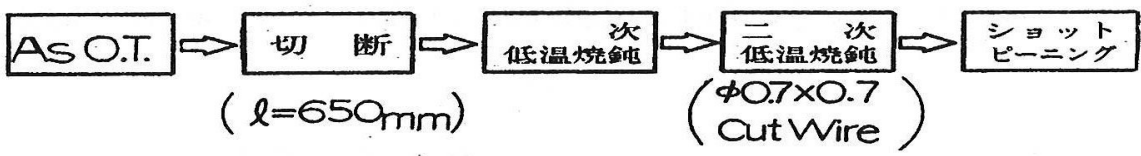

\begin{tabular}{|c|c|c|}
\hline 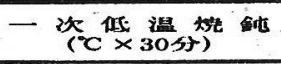 & 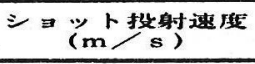 & 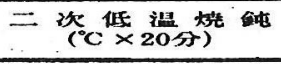 \\
\hline As O.T. & 74.4 & - \\
\hline 200 & 1 & 200 \\
\hline 300 & 1 & 4 \\
\hline 400 & 1 & 4 \\
\hline 420 & 37.2 & 1 \\
\hline 4 & 4 & 300 \\
\hline 1 & 4 & 400 \\
\hline 1 & 74.4 & 200 \\
\hline 1 & 4 & 300 \\
\hline 4 & 1 & 400 \\
\hline 4 & 124.0 & 200 \\
\hline 4 & 1 & 300 \\
\hline 4 & $\uparrow$ & 400 \\
\hline 450 & 74.4 & 200 \\
\hline
\end{tabular}

低温焼鈍・ショットピーニング・二次低温焼鈍と言う， 一般の弁ばねの処理工程と同じ工程で作成した。

一次低温焼鈍は, As O.T. $450^{\circ} \mathrm{C}$, ショット投射速 度は, $37.2 \mathrm{~m} / \mathrm{s} \sim 124.0 \mathrm{~m} / \mathrm{s}$, 二次低温焼鈍は, $200^{\circ} \mathrm{C}$ $\sim 400^{\circ} \mathrm{C}$ に変化させた。ただし，一次低温焼鈍温度を変 えた供試材についてはショット投射速度 $74.4 \mathrm{~m} / \mathrm{s}$ ・二 次低温焼鈍 $200^{\circ} \mathrm{C}$ に固定し, 疲れ強さに対する硬さの影 響を調べた。また，ショットピーニング・二次低温焼
鈍温度を変えた供試材については，一次低温焼鈍温度 $420^{\circ} \mathrm{C}$ (現行弁ばね処理温度)に固定し, 表面粗さ及び, 残留応力の影響について調べた。疲れ試験は, $10^{7}$ 回に おける平均疲れ強さを算出すべく，修正ステアケース 法に基づいて試験を行った。

\section{3. 実験結果}

3.1 一次低温焼鈍と疲れ強是 
一次低温焼鈍温度が，回転曲げ疲労における疲れ強 さにどのような影響を与えるかについて調べた，

図 2 に，低温焼鈍温度と硬さの関係を示す。硬さは 低温焼鈍温度 $350^{\circ} \mathrm{C}$ までは若干, 上昇し, それ以上の温 度では，大きく低下している。

ここで,一次低温焼鈍温度を As O.T. $450^{\circ} \mathrm{C}$ まで変 化させた場合の回転曲げ疲れ試験での疲れ強さを示す。 図 3 は，低温焼鈍温度と疲れ強さの関係を表したもの

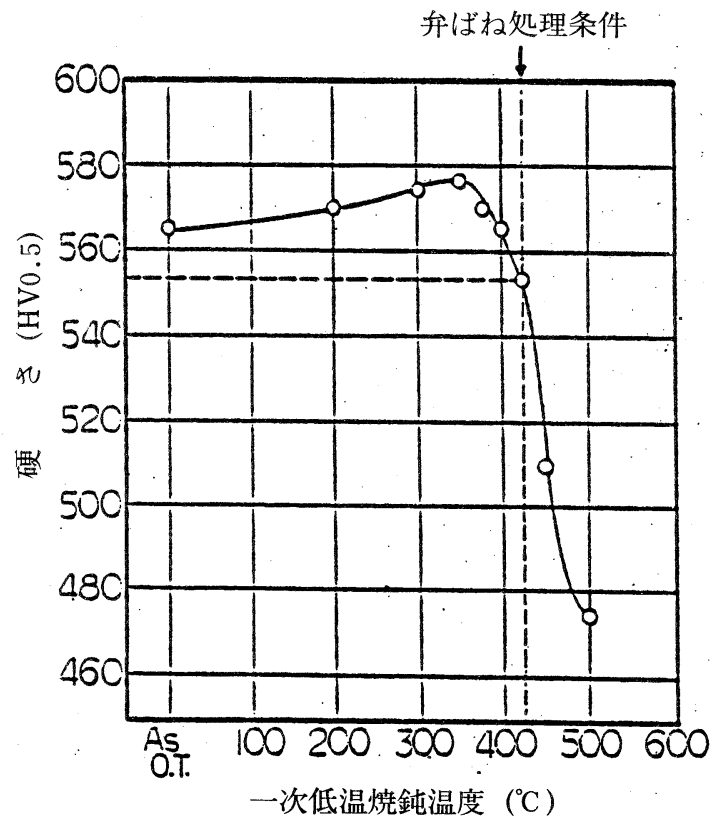

図2。低浛焼鈍温.度と硬さ

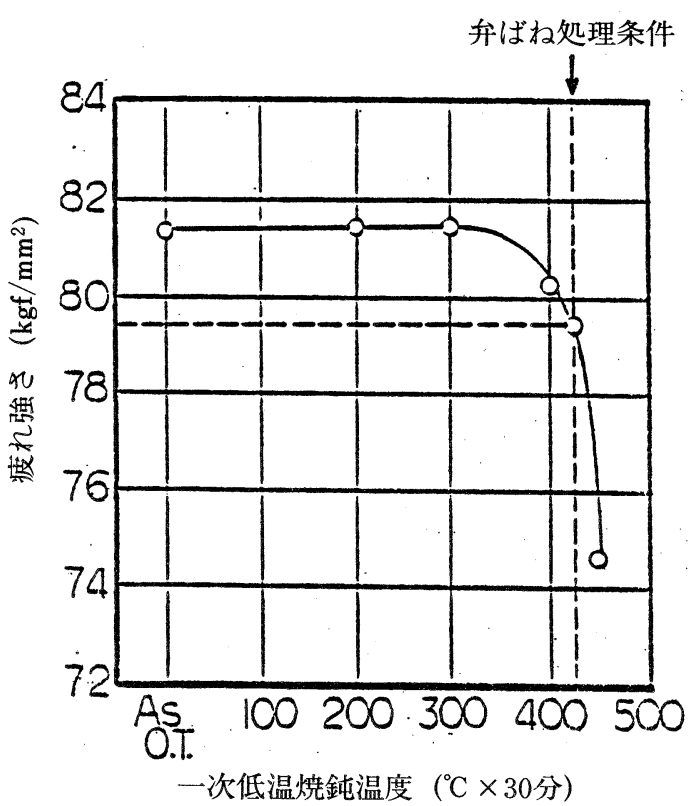

図3。低温焼鈍温度と疲孔強さ
である.ショット投射速度は $74.4 \mathrm{~m} / \mathrm{s}$ ，二次低温焼鈍 はAs O.T. 以外の供試材については $200^{\circ} \mathrm{C} て ゙ 20$ 分間施 行してある。

疲れ試験の結果, 一次低温焼鈍温度 $300^{\circ} \mathrm{C}$ までは, 疲 れ強さは,ほぼ一定であり $400^{\circ} \mathrm{C}$ 以上になると大きく低 下することがわかった。これは，図 2 に示す低温焼鈍 特性と同じ傾向を示している。

そこで図 4 に, 素線の硬さと疲れ強さの関係を示す.

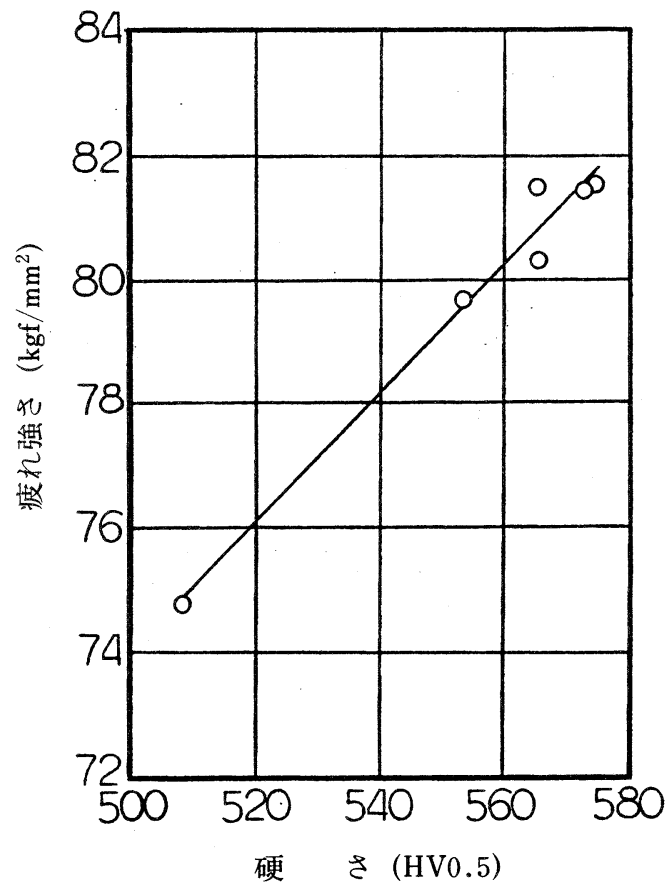

図4.絭線の硬さと疲れ強さ

この結果, 硬さと疲れ強さは, ほぼ比例関係にあるこ とがわかる。

\section{2 ショットピーニングと疲れ強さ}

ショットピーニングは, 疲れ強さを向上させる上で 有効な処理である。これは，素材表面に圧縮の残留応 力を形成し, 繰り返しにおける実働応力を緩和するた めである。しかし，ショットピーニングは，圧縮残留 応力を形成する一方，素材表面を荒らすという逆効果 にも成り得る。ここでは，ショット投射速度を， 37.2 $\mathrm{m} / \mathrm{s}, 74.4 \mathrm{~m} / \mathrm{s}, 124.0 \mathrm{~m} / \mathrm{s}$ と変之, 表面粗さ及び残留 応力を変之実験を行った.

図 5 に，表面粗さの実測例，図 6 に，ショット投射 速度と粗さの関係を示す。ショット投射速度が増すに 従って, 十点平均粗さ $(R z)$, 最大高さ $(R \max )$ ともに 増加している。 

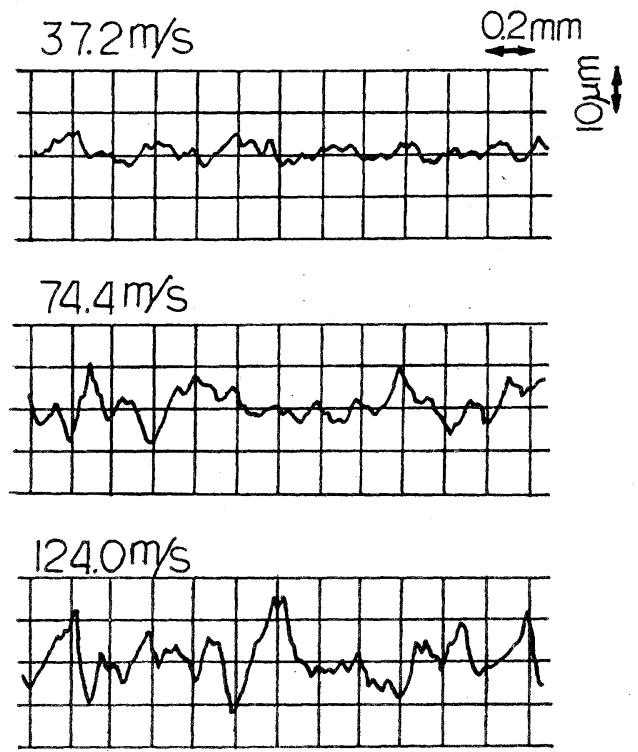

図5. 表面粗さ実測例

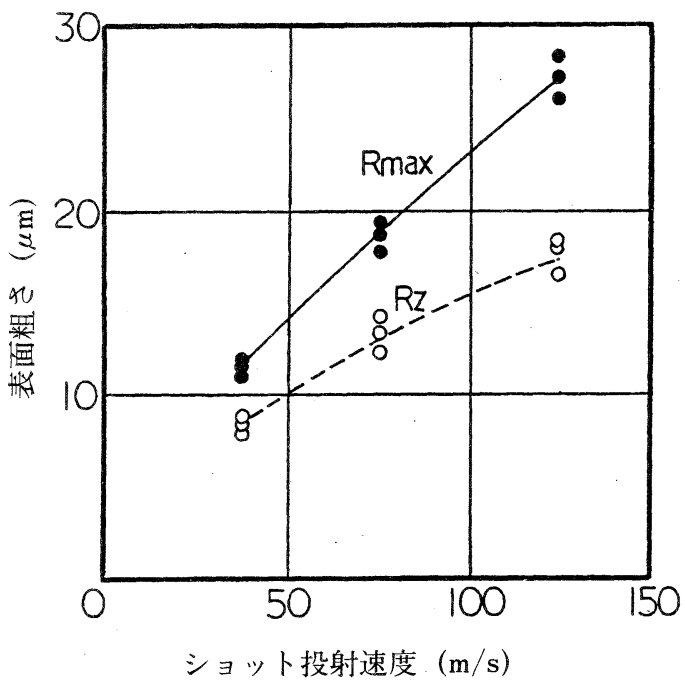

図6。ショット投射速度と表面粗さ

次に図 7 ・8 にショット投射速度・粗さと疲れ強さ の関係を示す。困中の温度は二次低温焼鈍温度を示し ている。ここでは, 疲れ強さは, ショット投射速度, 表面粗さが増大するに従い，低下している.

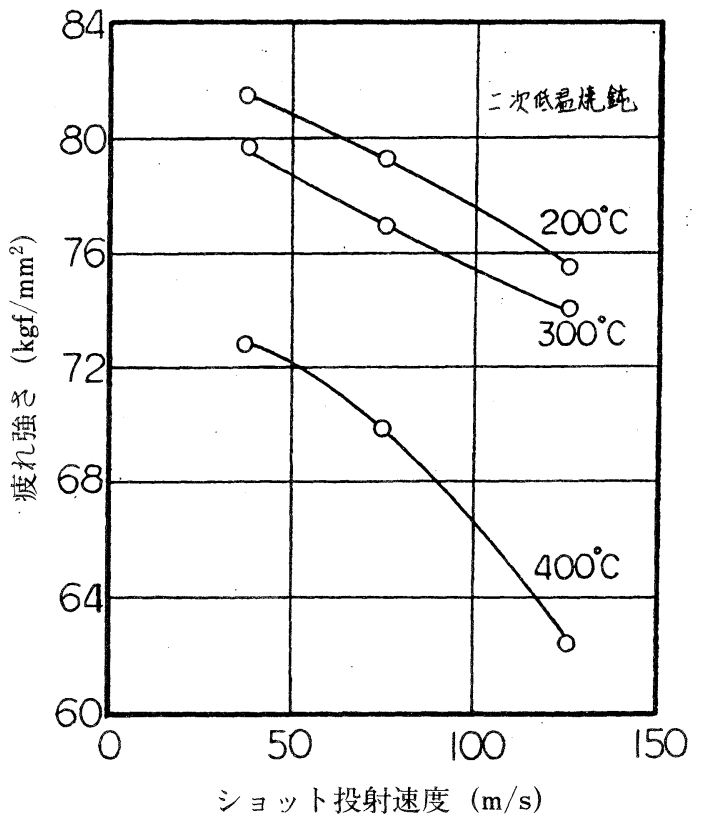

図7. ショット投射速度と疲れ強さ

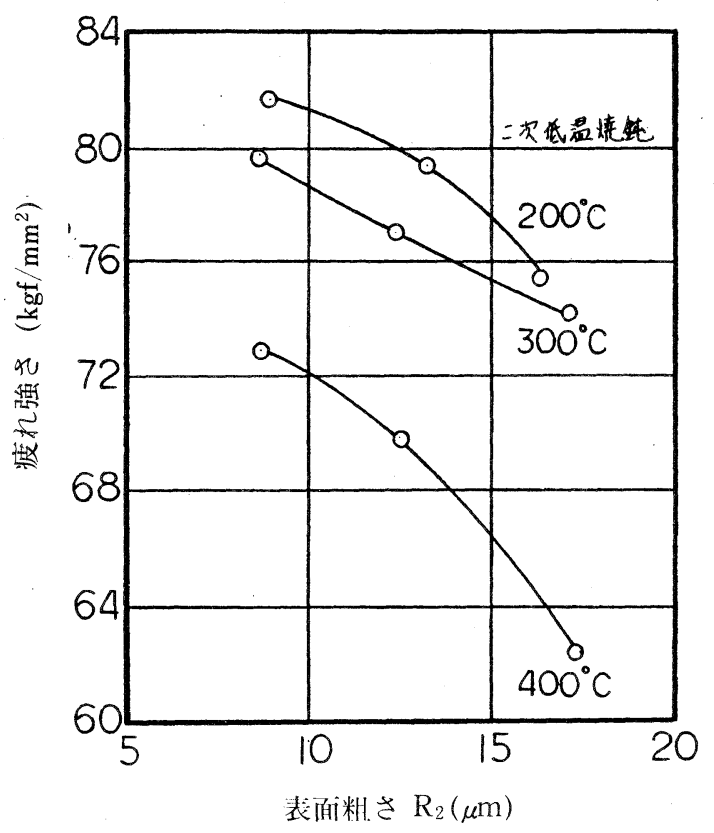

図8．表面粗さと疲れ強さ 
また, 残留応力と疲れ強さの関係についても調べた。 ここでは，供試材へのショット投射速度を $37.2 \mathrm{~m} / \mathrm{s}$ $\sim 124.0 \mathrm{~m} / \mathrm{s}$ とし, 二次低温焼鈍温度を, $200^{\circ} \mathrm{C} \sim 400^{\circ} \mathrm{C}$ と変え，それぞれ同じ表面粗さで残留応力分布を変化 させた。図9に，ショット投射速度の違いによる残留 応力分布の変化を示す。ショット投射速度が速くなる に従い残留応力分布のピークの位置が表面より深くな っている. また，最表面における圧縮残留応力は，シ ヨット投射速度が遅い方が高く, 投射速度が増すほど 低下している。これは，ショット投射速度が速くなる と圧縮残留応力のピークは深くなるが，投射速度が遅 いものに比べ，表面付近の塑性変形量が大きくなり， 最表面では逆に残留応力が低くなるためであると考え られる。

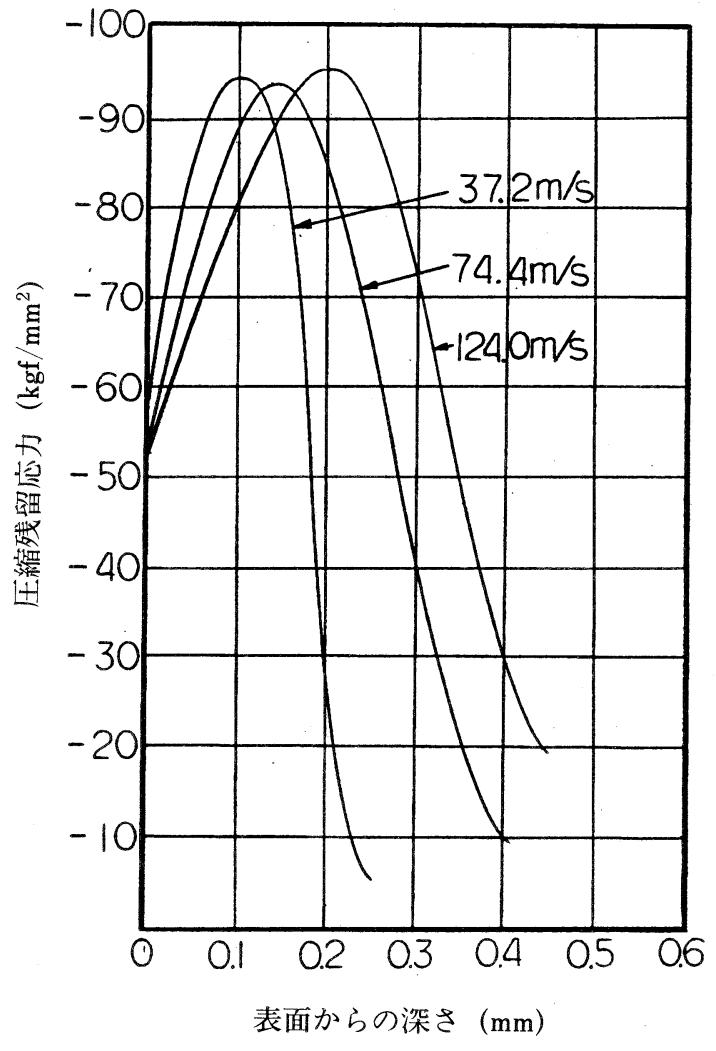

図9．残留応力分布

図 10 に, 二次低温焼鈍温度と, 表面の圧縮残留応力 の関係を示す。ここでは，処理温度が高くなるに従い 圧縮残留応力の低下が認められる。これは, 加熱によ る残留応力の解放によるものと考えられる。

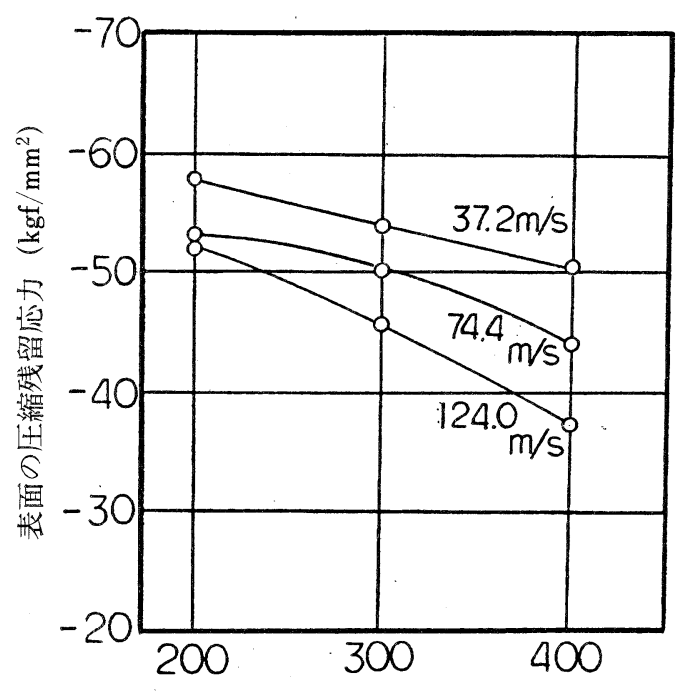

二次低温焼鈍温度 $\left({ }^{\circ} \mathrm{C}\right)$

図10．表面残留応力値

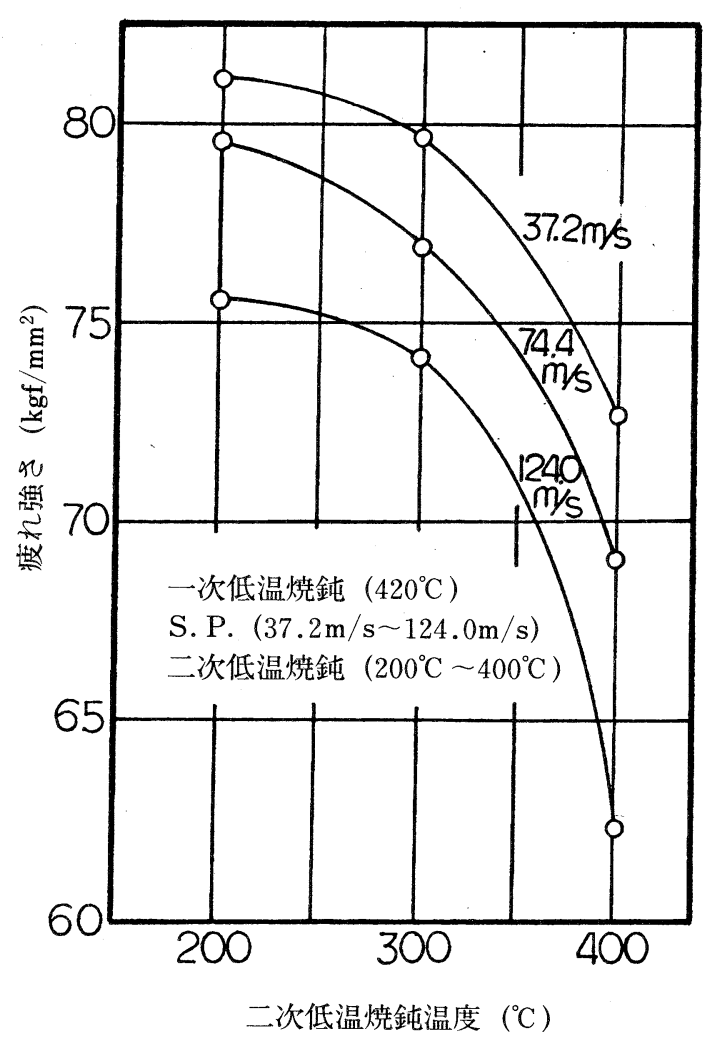

図11，二次低温焼鈍と疲れ強さ 
これらの結果を基に, 図 11 に疲れ強さとの関係を調 べた。二次低温焼鈍温度が高くなるに従い，表面の圧 縮残留応力が低下し, 疲れ強さも低下している。また ショット投射速度が遅いものほど，疲れ強さは高くな る. 従って, 中村式回転曲げ疲れ試験に関しては，表 面粗さが小さく，表面の圧縮残留応力の高いショット ピーニングが有効である。これは，回転曲げ疲れ試験 が両振りのため, 供試材の最表面の状態(粗さ・残留応 力）の影響度が大きくなるためと思われる。

\section{3 折損破面}

図 12 に，折損破面の一例を示す。破面観察の結果， 供試材はすべて材料表面を起点として折損しており，
介在物による折損は認められなかった。

図 12 において, 左側の破面は応力が高く $(83.0 \mathrm{kgf} /$ $\left.\mathrm{mm}^{2}\right)$ 早期 $\left(2.81 \times 10^{5}\right.$ 回 $)$ にて折損したもの, 右側の破面 は, 応力が低く $\left(81.5 \mathrm{kgf} / \mathrm{mm}^{2}\right)$ 長寿命側 $\left(1.553 \times 10^{7}\right.$ 回)で折損したものの例である.

早期に折損したものは，表面から放射状にき裂が進 行し，折損に至るまでの繰り返し数が多くなるにつれ き裂は，ショットピーニングの効果により，渦を巻く 形で進行する.また $10^{7}$ 回付近の長寿命で折損したもの については，表面からせん断クラックが入った後疲労 き裂が進行することがわかった。

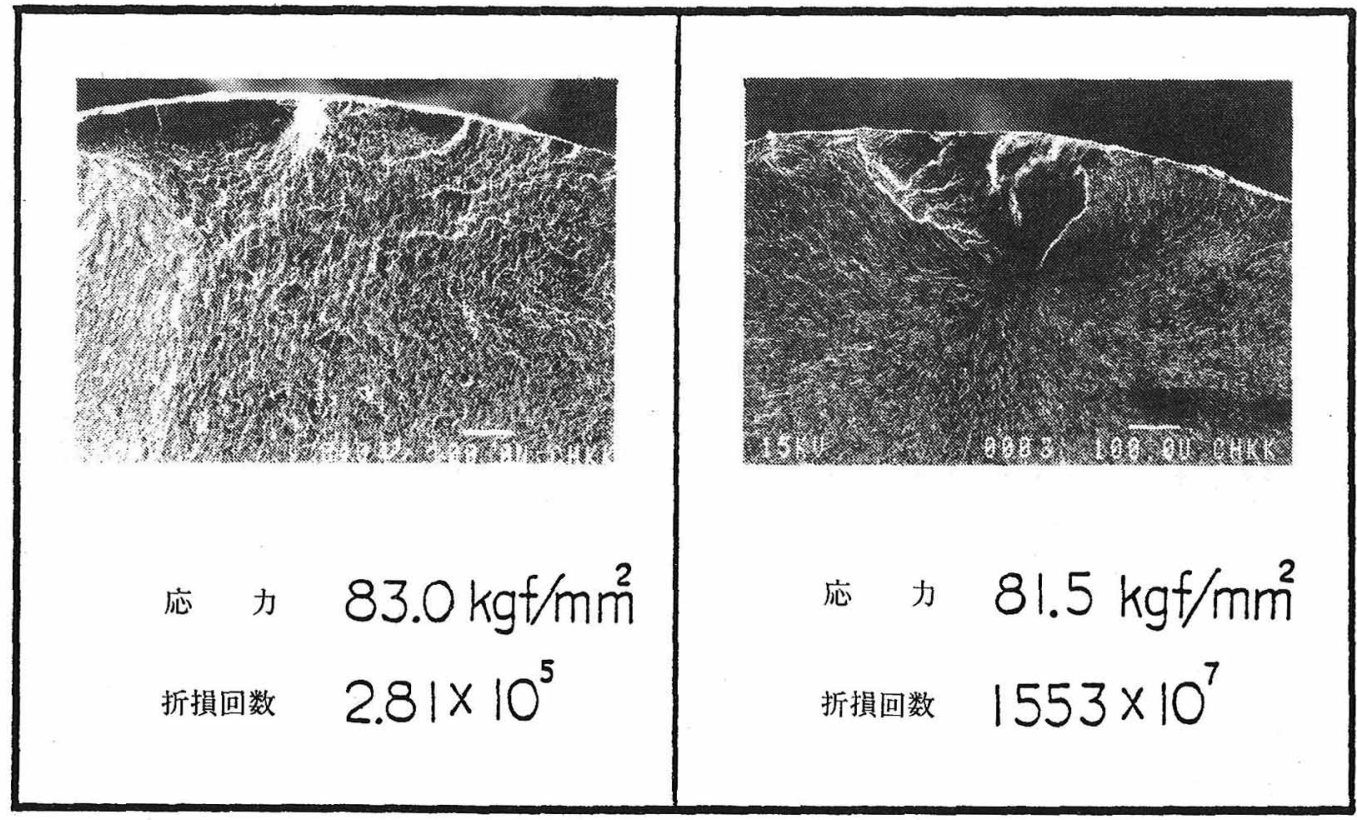

図12. 折損破面例

\section{4. まとめ}

中村式回転曲げ疲れ試験による疲れ強さ評価の結果 以下のことがわかった。

1) 疲れ強さは, 材料の硬さ（引張強さ）に比例する. そのため, 回転曲げ疲れ試験では，通常弁ばねに施行 する一次低温焼鈍 $\left(420^{\circ} \mathrm{C}\right)$ より低い温度 $\left(350^{\circ} \mathrm{C}\right.$ 以下)で 施行することにより高い耐久性が得られる。

2) 回転曲げ疲れ試験用供試材は，その折損形態(表 面起点) から, 弁ばね状態に比べ表面の荒れの感受性が
高く，ショットピーニングによる表面の荒れは，弁ば ねより大きく疲れ強さ低下につながる，従って今回の 実験では投射速度の最も遅い, 表面粗さの小さい 37.2 $\mathrm{m} / \mathrm{s}$ のものが疲れ強さが高い結果となった。

3 ）二次低温焼鈍は， $200^{\circ} \mathrm{C}$ で処理したものが，疲れ 強さが最も高く $, 300^{\circ} \mathrm{C}, 400^{\circ} \mathrm{C}$ になると圧縮の残留応 力の減少により疲れ強さは急激に低下する。 